http://jmscr.igmpublication.org/home/

ISSN (e)-2347-176x ISSN (p) 2455-0450

crossref DOI: https://dx.doi.org/10.18535/jmscr/v7i12.78

Journal Of Medical Science And Clinical Research

\title{
Role of hypoalbuminemia to predict pregnancy induced hypertension and its complications
}

Authors

\author{
Dr Kanchan Kumari ${ }^{1}$, Dr Usha Kumari², Dr Pankaj Bhushan ${ }^{3}$ \\ ${ }^{1}$ Assistant Professor, Department of Biochemistry, VIMS, Pawapuri, Nalanda \\ ${ }^{2}$ Associate Professor, Department of Biochemistry, VIMS, Pawapuri, Nalanda \\ ${ }^{3}$ Assistant Professor, Department of Biochemistry, ANMMC, Gaya, Bihar \\ Corresponding Author \\ Dr Usha Kumari
}

\section{Introduction}

Previously pregnancy induced hypertension was called "toxaemia of pregnancy". This is devastating state of pregnancy leading to severe maternal and foetal morbidity and mortality. Pregnancy induced hypertension is classified as pre-eclampsia and eclampsia. Pre-eclampsia is pregnancy induced hypertension having hypertension associated with proteinuria and generalized edema without convulsion, whereas eclampsia is similar condition with convulsions. Hypertension developing after 20th week of gestation has been categorized as pregnancy induced hypertension. Pregnancy induced hypertension affects about 10 percent of total pregnancies in world. In India it affects about 810percent of total pregnancies.

Hypertensive disorder of pregnancy may lead to endometrial endothelial dysfunction and systemic endothelial dysfunction. This results in series of changes leading to decrease production of vasodilators and increase production of vasoconstrictors causing vasospasm and inadequate blood supply in placenta. There is abnormal implantation. All these contribute to endothelial damage in placenta resulting in secretion of inflammatory mediators from placenta such as various cytokines. There is uric acid increase prior to development of hypertension in pregnancy induced hypertension leads to formation of super oxide radicals which in turn causes further damage of endothelial cells. Albumin extravasates into extra vascular compartment from intravascular compartment of damaged endothelium. There is vasospasm in liver leads to decreased function of liver and elevated liver enzyme. This leads to decreased synthesis of albumin. .Albumin also extravasate from renal endothelial cells leads to proteinuria. There is also hemodilution during pregnancy. All these contribute to hypoalbuminemia and development of edema and preeclampsia.

\section{Aim \& Objective}

Aim of our study is to estimate serum total protein, albumin, $\mathrm{A} / \mathrm{G}$ ratio and other biochemical parameters in pre-eclampsia and eclampsia and compare it with normal non pregnant women of child bearing age and in pregnant women of different trimester of pregnancy to predict the development of toxaemia of pregnancy so that maternal and foetal complications can be prevented. 


\section{Material and Method}

Present study was carried out at Vardhmaan institute of medical sciences, Biochemistry department and Sadar hospital, Biharsharif attached to VIMS, Pawapuri. Total 110 cases were selected for study. Out of which 15 cases were clinically normal non pregnant women of reproductive age group. 45 cases were normal pregnant women of different trimester of pregnancy. 60 cases were control group. 50 cases of were taken for study out of which 25 cases were pre-eclampsia and 25 cases were of eclampsia. All cases were selected from opd and emergency ward of Sadar hospital Biharsharif, Nalanda attached to Vardhmaan institute of medical sciences, Pawapuri, Nalanda. Blood Pressure of cases and control was measured and blood sample for biochemical investigation was collected. Biochemical investigation was done in biochemistry department VIMS, Pawapuri,
Nalanda. Criteria of inclusion were non smokers, non-alcoholic and free from any metabolic disorder. Detailed history was taken and detailed clinical examinations were done.

Estimation of total proteins was done by modified biuret method. Estimation of serum albumin was done by Bromo-cresol Green method. These method have high sensitivity and specificity. Other biochemical investigation such as plasma glucose and uric acid etc was also done.

\section{Observation}

In this study out of 110 cases 15 cases were clinically normal non pregnant women were of reproductive age group and 45 cases were normal pregnant women of different trimester of pregnancy, 5o cases of toxaemia of pregnancy were chosen for study of which 25 cases were categorized as preeclampsia and 25 cases as eclampsia.

\begin{tabular}{|l|c|c|c|c|}
\hline Variables & Range & Mean & $+/$-SD & Significance $\mathrm{p}$ value \\
\hline \multicolumn{5}{|c|}{ Non-pregnant No of cases - 15 } \\
\hline Serum total protein & $6.3-7.7$ & 7.05 & 0.550 & $>0.05 \mathrm{NS}$ \\
\hline Serum albumin & $3.3-5.1$ & 4.19 & 0.604 & $>0.02 \mathrm{NS}$ \\
\hline Serum globulin & $2-3.8$ & 2.8 & 0.486 & $>0.05 \mathrm{NS}$ \\
\hline A\G ratio & $1-2.27$ & 1.59 & 0.45 & $>0.1 \mathrm{NS}$ \\
\hline
\end{tabular}

\begin{tabular}{|l|c|c|c|c|}
\hline Serum total protein & $6.2-7.7$ & 7.04 & 0.498 & $>0.01 \mathrm{NS}$ \\
\hline Serum albumin & $2-5$ & 3.74 & 0.852 & $>0.05 \mathrm{NS}$ \\
\hline Serum globulin & $2.3-4.6$ & 3.30 & 0.675 & $>0.1 \mathrm{NS}$ \\
\hline A/G ratio & $0.44-2.0$ & 1.23 & 0.489 & $>0.1 \mathrm{NS}$ \\
\hline \multicolumn{4}{|l|}{ Normal pregnancy second trimester No of cases-14 } \\
\hline Serum total protein & 6.47 .8 & 7.22 & 0.512 & $>0.1 \mathrm{NS}$ \\
\hline Serum albumin & $3.5-5.2$ & 4.45 & 0.553 & $>0.05 \mathrm{NS}$ \\
\hline Serum globulin & $2.5-3.9$ & 2.80 & 0.361 & $>0.1 \mathrm{NS}$ \\
\hline AlG ratio & $1.04-1.19$ & 1.62 & 0.320 & $>0.01 \mathrm{NS}$ \\
\hline
\end{tabular}

\begin{tabular}{|c|c|c|c|c|}
\hline \multicolumn{5}{|c|}{ Normal pregnancy third trimester No of cases-16 } \\
\hline Serum total protein & $6.3-7.82$ & 7.286 & 0.426 & $>0.01 \mathrm{NS}$ \\
\hline Serum albumin & $3.1-5.1$ & 4.07 & 0.498 & $>0.01 \mathrm{NS}$ \\
\hline Serum globulin & $2.4-4.1$ & 3.20 & 0.452 & $>0.02 \mathrm{NS}$ \\
\hline A|G ratio & $0.74-2.0$ & 1.32 & 0.296 & $>0.05 \mathrm{NS}$ \\
\hline \multicolumn{5}{|c|}{ Pre-eclampsia No of cases-25 } \\
\hline Serum total protein & $5.8-6.9$ & 6.26 & 0.358 & $>0.01 \mathrm{NS}$ \\
\hline Serum albumin & $2-3.6$ & 2.67 & 0.46 & $<0,02$ sig \\
\hline Serum globulin & $2.6-4.3$ & 3.54 & 0.44 & $<0.02 \mathrm{sig}$ \\
\hline A $\backslash G$ ratio & $0.50-1.4$ & 0.79 & 0.234 & $<0.05 \mathrm{sig}$ \\
\hline \multicolumn{5}{|c|}{ Eclampsia No. of cases-25 } \\
\hline Serum total protein & $4-6.4$ & 5.74 & 0.566 & $<0.01$ sig \\
\hline Serum albumin & $1.8-3.4$ & 2.52 & 0,456 & $<0.02$ sig \\
\hline Serum globulin & $1.2-3.9$ & 3.18 & 0.550 & $>0.1 \mathrm{NS}$ \\
\hline$A \backslash G$ ratio & $0.54-2.64$ & 0.805 & 0.406 & $<0.01 \mathrm{sig}$ \\
\hline
\end{tabular}

This table shows comparison of total protein, serum albumin serum globulin, AlG ratio in different group of cases in gm/dl. 
Fig- Histogram showing comparison of total protein, serum albumin, serum globulin, AlG ratio in different group of cases

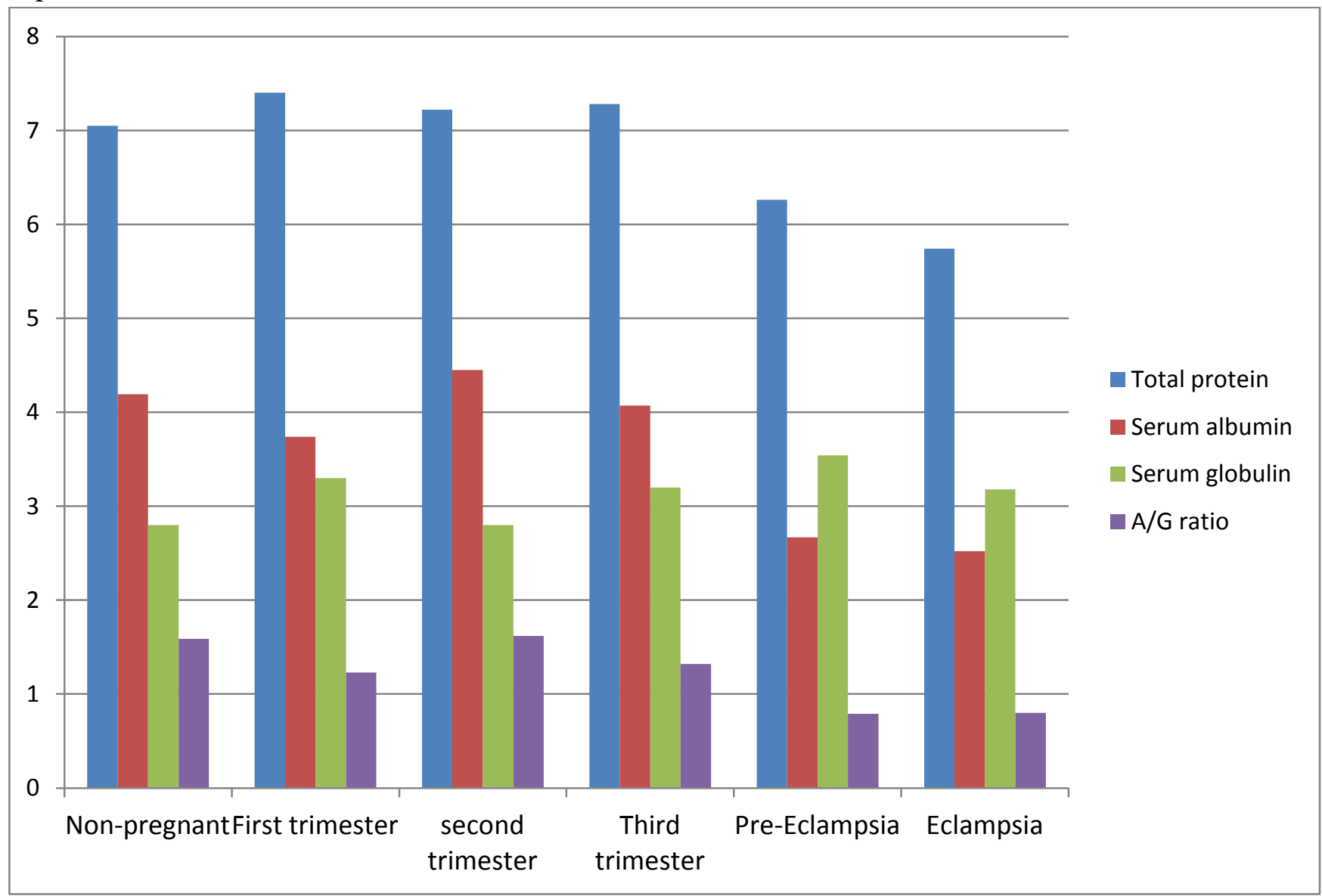

Above table and histogram shows there is no significant change in mean serum total proteins in normal non pregnant and pregnant women.

However there was significant decrease in mean serum proteins in eclampsia compared to control group. There is no significant change in mean serum albumin in non pregnant and normal pregnancy, there is significant decrease in mean serum albumin in preeclampsia and eclampsia compared to control group. Also there is no significant change in mean serum globulin in non pregnant, normal pregnancy and eclampsia, but significant increase in pre eclampsia compared to control group. There is change in $\mathrm{A} / \mathrm{G}$ ratio in non pregnant and normal pregnant women, but there significant decrease in pre eclampsia and eclampsia compared to control group.

\section{Discussion}

In our study 110 cases were taken for study. Out of which 15 cases were normal non pregnant women of child bearing age. In which serum albumin was 4.19+/-0.604,p-value>0.02NS.Serum albumin in normal pregnant women of first, second and third trimester were $3.74 \mathrm{gm} / \mathrm{dl}+/-$ 0.852 , p-value $>0.05 \mathrm{NS}, \quad 4.45 \mathrm{gm} / \mathrm{dl}+/-0.553, \mathrm{p}-$ value $>0.05 \mathrm{NS}, \quad 4.07 \mathrm{gm} / \mathrm{dl}+/-0.498 \mathrm{p}$ value $>$ $0.01 \mathrm{NS}$ respectively. Abbasi-Ghanavat M, Greer LG, Cunningham also found serum albumin in non pregnant normal pregnancy of first, second and third trimester were $4.1 \mathrm{gm} / \mathrm{dl}, 3.1-5.1 \mathrm{gm} / \mathrm{dl}$, $2.6-4.5 \mathrm{gm} / \mathrm{dl}$ and $2.3-4.2 \mathrm{gm} / \mathrm{dl}$ respectively. In our study serum albumin were in this range. There is slight decrease in serum albumin but nonsignificant this is probably duo to hemodilution and physiological change of pregnancy itself.

In pre-eclampsia serum albumin was $2.67 \mathrm{gm} / \mathrm{dl}+\downarrow$ $0.46 \mathrm{p}$-value $<0.02 \mathrm{sig}$.ln eclampsia serum albumin was $2.56+/-0.456 \mathrm{gm} / \mathrm{dl} \mathrm{p}$-value $<0.02$ sig. There is 
significant change in serum albumin in preeclampsia and eclampsia compared to control group. Stosur $\mathrm{S}$ et al and Friedman RB et al also found that serum total protein and albumin are more decreased in severe preeclampsia than mild preeclampsia. In preeclampsia decreased serum albumin is duo to leaking of albumin from intravascular to extra vascular space and also from inflamed renal endothelium. Abnormally hypoalbuminemia is associated with poor circulation through vascular system and less than $2 \mathrm{gm} / \mathrm{dl}$ is associated with significant edema.

\section{Summary and Conclusion}

Pregnancy induced hypertension is one of the major challenging situation in emergency ward of obstetrics and gynaecology Department, particularly in underdeveloped and poorly developed country. Sometimes pregnancy induced hypertension patients may undergo eclamptic condition with severe edema, convulsion, unconsciousness and blurring of vision even death. This condition needs combined energetic and efficient management approach between obstetrician and physician as well as anaesthetic in ICU to prevent maternal and foetal morbidity and mortality.

Those patients who are going to develop hypoalbuminemia and proteinuria with change in $\mathrm{A} / \mathrm{G}$ ratio or significant decrease in $\mathrm{A} / \mathrm{G}$ ratio during their second trimester should be considered as high risk patient for developing preeclampsia and eclampsia. These patients should be given planned treatment protocol for prevention of pregnancy induced hypertension. So that early diagnosis and treatment could prevent maternal and foetal morbidity and mortality.

\section{Bibliography-}

1. Muti M, Tshimanga M, Notion GT, Bangur D, Chonzi P, Prevalence of pregnancy induced hypertension and pregnancy outcome among women seeking maternity services in Harare, Zimbawe, BMC. Cardiovac Disorders.2015: 15:111.
2. Abbasi-Ghanavati M,Greer LG, Cunningham FG; pregnancy and laboratory studies: a reference table for clinicians. Obstet Gynecol. 2009 Dec; 114(6):1326-3.

3. Candiano G, petretto A. Bruschim., Sentuccit, Dimuccio V; Prunotto M; Gusmano R; Urbani; GhiggoriG. The oxide-redox potential albumin: methodological approach and relevance to human disease J. Proteomics.2009; 73:188-195[Pub Med]

4. Salako BL, Odukogbe AT, Olayemi O, Adedapo KS, Aimaku CO,Alu FE,Ola B,East Afr. Med.J 2003 Aug; 80(8): 424-8.

5. Soma H, Yoshida K, Mukaida T, Tabushi $\mathrm{Y}$, Morphologic change in hypertensive plecenta contribution Gynaecol obstet. $1982 ; 9: 358-75$. 